\title{
ACCOUNTING AND MANAGEMENT ISSUES
}

\author{
[Účetnictví a otázky řízení] \\ Jaromír Lazar ${ }^{1}$, Ivana Koštuříková ${ }^{2}$ \\ ${ }^{1}$ Slezská univerzita, Obchodně podnikatelská fakulta, Univerzitní nám. 1934/3,733 40 Karviná \\ Email:lazar@opf.slu.cz \\ ${ }^{2}$ Slezská univerzita, Obchodně podnikatelská fakulta, Univerzitní nám. 1934/3,733 40 Karviná \\ Email:kosturikova@opf.slu.cz
}

\begin{abstract}
Accounting is an important source of information for the various stages of business management. The accounting information has affected the quality of management and top management's decision-making significantly, becoming crucial for the competitiveness of companies in the European and world market. The accounting records of all companies should be based on the same principles and methods to present comprehensible and mainly comparable results. The present accounting system has been in the Czech Republic for two decades and there are both system and legislative gaps and simple mistakes. The authors reflect on the existing process of accounting reform and related accounting requirements of internal economic management. Accounting problems are defined at different levels: economic philosophy, system deficiencies, legislative gaps, erroneous interpretations of legislations. These issues are affected by the syndrome of the status quo. This causing difference between the theory and practical management needs. The authors say the need for continuous education in this area.
\end{abstract}

Keywords: accounting problems, accounting theory, management needs, reform.

JEL classification: $\mathrm{P} 11$

Doručeno redakci: 19.8.2014; Recenzováno: 26.8.2014; 29.8.2014; 23.9.2014; Schváleno k publikování: 23.9.2015

\section{Úvod}

Nedostatky v systému účetnictví vzhledem k potřebám řízení mají několik úrovní. Jsou to nedostatky systémové, $\mathrm{z}$ neaktuálních předpisů, chybných výkladů předpisů i prosté omyly. Ačkoliv jsou známy, chybí vůle $\mathrm{k}$ jejich nápravě. Je jasné, že jejich náprava na úrovni zákona je velmi obtížná, předpisy nižší právní síly je ale možné měnit snadněji. Napravovat omyly $\mathrm{v}$ účetních diskusích na internetu je nejsnazší, ale velmi pracné. V těchto diskuzích se vyjadřuje prakticky každý, ale často se neuvažuje na úrovni mezinárodních účetních standardů IAS a IFRS. Tento článek se snaží upozornit na řadu nedostatků a navrhnout jejich řšení.

Nedostatky mohou být řazeny podle jejich úrovně, jak znázorňuje následující schéma:

Obrázek 1: Problémy v systému účetnictví podle úrovně

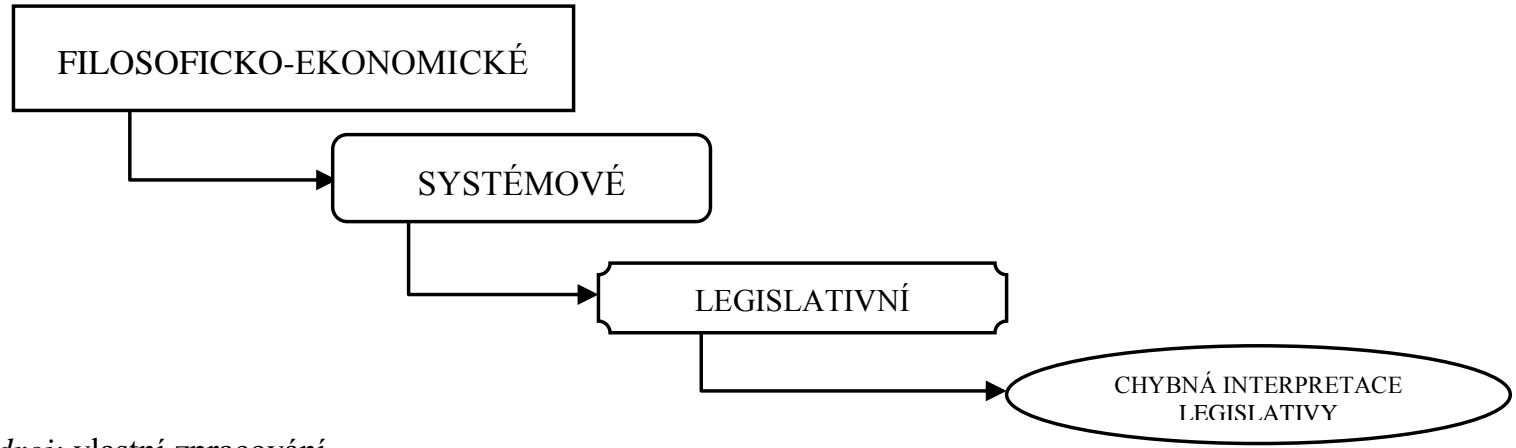

Zdroj: vlastní zpracování 
Pozornost bude věnována tomu, jak je možno tyto nedostatky $\mathrm{z}$ pohledu teoretickometodologického vůbec uchopit, zařadit a prakticky využít.

\section{Problémy filosoficko-ekonomické}

\subsection{Pojetí majetku ve světě}

Ve výkladu ekonomických teorií ve školní výuce se omezujeme pouze na evropské a anglosaské systémy. Informace o ostatních systémech jsou $\mathrm{v}$ našem prostoru prakticky nedostupné (jazyková bariéra zde hraje rovněž významnou roli). Jeden z autorů získával následující informace od svých studentů doktorského studia $\mathrm{z}$ arabského (prakticky islámského) světa.

Jedním ze základních rozdílů mezi evropskými spolu s anglosaskými systémy a islámským pojetím je prístup $\mathrm{k}$ majetku a názoru na opravy a technická zhodnocení. $\mathrm{V}$ naší oblasti je daňově zvýhodněná oprava a těžce jsou postihovány modernizace. Naše předpisy, které se $\mathrm{k}$ tomu vztahují, důsledně konzervují majetek. V této šikanózní roli vynikaly zejména finanční úřady. Nebylo možné modernizovat výrobní linky, stroje a budovy jinak než $\mathrm{v}$ investičním režimu. Ve srovnávané zeměpisné oblasti, o které hovoříme, je tomu právě naopak. Po každém zásahu do majetku by měl vyjít jako modernizovaný, se zlepšenými vlastnostmi. Aby po opravách skončil na stejné technické úrovni jako v době svého vzniku, je v podstatě nepřijatelné.

V průběhu vývoje zde byly určité možnosti jiného pojetí majetku. I když naše účetnictví má blíže k evropskému modelu, v našich podmínkách jsme se soustředili na anglosaský model a evropský (v podstatě německý) byl upozaděn. Významný představitel německé teorie oceňování a obnovy majetkové podstaty podniku ${ }^{1}$ Schmallenbach upadl do zapomenutí a s ním i jeho progresivní názory.

\subsection{Kritické hlasy ve světě}

Dalo by se pokračovat ve výčtu dalších neduhů účetnictví, ale musíme si uvědomit, že jsou problémy, které řeší účetnictví neustále. Jestliže je nějaký problém uspokojivě vyřešen, je to často na úkor jiné oblasti. Jako př́klad lze uvést koncepční záležitost účetnictví: zvolit produkční nebo realizační princip? Každý z těchto principů má své výhody a nevýhody, ale je nutno se rozhodnout pro jeden $\mathrm{z}$ nich. Je pravda, že české účetnictví to u zásob nedokázalo, jak bude prezentováno $\mathrm{v}$ dalším textu.

Podle Kovandy (2009) španělský profesor ekonomie Jesús Huerta de Soto tvrdí, že k neblahé situaci přispěly i moderní účetní principy. Tento ekonom konstatuje následující:

„Účetnictví je mluva byznysu. Účetnictví také nevzniklo ze dne na den, záznamy peněžních obratů máme už ze dvanáctého století. Uživali je již v antickém Řecku nebo v ptolemajovském Egyptě. Účetnictví se tedy vyvíjelo evolučně - rozvíjely je generace obchodníků či prưmyslnikư, přičemž stálo na několika principech.

Z nich ten kličový byl princip uvážlivé šetrnosti, opírajici se o pojem historické ceny - ceny zaplacené při transakci. Jenom pokud byla tržni cena nižši než historická, docházelo ke snižení účetni hodnoty. Pokud byla vyšší, drželi se historické ceny.

\footnotetext{
${ }^{1} \mathrm{~V}$ tomto článku bude nadále použiváno označení „podnik“, i když je platné legislativy nově použiván výraz „obchodní závod“. Autoři jakož i legislativa, která je v článku zmiňována, ještě ve své době toto označení neznala.
} 
$V$ uplynulých letech byla evoluce účetnictví zpřetrhána - nazývá se to Mezinárodní pravidla účetnictví. Princip šetrnosti byl nahrazen principem ,, fair value". Je to trochu trik: kdo by byl proti férovému oceňováni? Tento „,érový" princip vede $k$ oceňováni nikoli na základě ceny při transakci, nýbrž na základě aktuálni tržni ceny. Jenže kolísavost trhů je tak značná, že účetni bilance pak pozbývají veškerého smyslu. V dobách boomu jsou neopodstatněně nafouklé, což podnikatele a firmy podněcuje $k$ dalši investični činnosti, $k$ spotřebé, $k$ podstupování dalšího rizika - prostě k euforii.

Účetnictví, po generace doprovodný jev uvážlivého obchodování, se tak mění ve stimul, jenž od uvážlivosti odvádí. Trh kolisá, a tak jsme jeden den účetně milionárí, druhý den nám hrozí bankrot a dožadujeme se kapitálových injekcí. Nové účetnictví násobí projevy boomů a stejně tak i propadů. Idea, že bilance by měly odrážet tržní ceny, je velmi hloupá. Jestliže je nové účetnictvi smrtíci pro bankéře, je smrtící i pro ten obchi̊dek na rohu.

Je třeba co nejrychleji zrušit všechny ty reformy účetních pravidel, prováděné v posledních letech... Bylo to stupidni rozhodnutí Evropské komise."

Problematikou používáním účetních metod na bázi spravedlivých cen nebo využití cen historických se rovněž zabývali Rebecca Toppe Shortridge, Amanda Schroeder a Erin Wagoner (2006), jakož i Hans Bonde Christensen a Valeri V. Nikolaev (2013). Také další ekonomové jako Robert Rubin ${ }^{2}$ nebo Paul De Grauwe ${ }^{3}$ se shodují na škodlivosti nových účetních pravidel. Tato pravidla nevygeneroval trh, ale státní byrokratické aparáty, které těmito pravidly zpřetrhaly staletou evoluci. Ony aparáty měnily zaběhlý ráa snad i proto, že v dobré míře zamýšlely účetnictví sjednotit, harmonizovat či standardizovat. Dělo se tak ovšem nikoli „zdola", přirozeným jednáním ekonomických subjektů, které následují rozličné podněty, leč „shora" - úřednickými výnosy. Co je na pováženou, snahy o umělou standardizaci a harmonizaci jsou patrné v mnoha jiných oblastech, zdaleka ne jen v účetnictví.

\section{Systémové nedostatky}

\subsection{Procesní řízení}

V př́ibuzných oborech, jako je management a další, se často hovoří o procesním řízení. Je nutno si uvědomit, že nejprve existovalo procesní účetnictví, které sledovalo výrobní linku, a $\mathrm{v}$ návaznosti na to se dá hovořit o procesním řízení. Reformy $\mathrm{v} 70$. letech ale byly postaveny na odpovědnostním účetnictví (střediska $\mathrm{s}$ odpovědným vedoucím) a tento model přetrvává v účetním myšlení dosud. Mezitím z jiných proveniencí přichází teoretická nástavba procesního řízení, ale u nás k ní chybí základní předpoklad - procesní účetnictví.

Tvorba řídicích systémů pak směřuje $\mathrm{k}$ vytváření mohutných datových struktur, které jsou řešeny nesystémově - tedy mimo systém účetnictví. Je otázkou, proč neřešit celý problém systémově, tedy př́mo v systému účetnictví. Lze konstatovat, že vše už tu jednou bylo, ale za jiných podmínek, kdy rrízení bylo pseudořízením podřízeným politickým cílům. Ale současná legislativa ani neumožňuje použít podnikům, které by o to stály, použít metody ověřené už bat'ovskou školou nebo modernější, např. řízení pomocí marže jakožto základ controllingových metod.

\footnotetext{
${ }^{2}$ Webový portál Bloomberg. Robert Rubin Says Mark-to-Market has Done 'Damage' (Update2) [online]. [vid. 2. srpna 2014]. Dostupné z http://www.bloomberg.com/apps/news?pid=newsarchive\&sid=aeaJxuGtTSbc\&refer =home

${ }^{3}$ Webový portál Europedebate [online] [vid. 17. srpna 2012]. Dostupné z http://europedebate.ie/dialogue-profpaul-de-grauwe-power-economic-ideas/
} 


\subsection{Reforma účetnictví $\mathrm{v}$ devadesátých letech}

Byla reforma opravdu reformou? Slovo „reforma“ je možné dát do uvozovek, protože vzniká otázka, zda opravdu šlo o hlubší reformu nebo jen o přečíslování účtů s některými dalšími úpravami. Na základním principu realizovaného a vyprodukovaného výsledku hospodaření se nezměnilo v podstatě nic a proto i nadále patří české účetnictví do tzv. „smíšeného typu“. Konkrétně u zásob se materiál účtuje podle principu produkčního a zboží podle principu realizačního.

Z hlediska gnozeologického tedy můžeme charakterizovat linii vývoje (nejen u zásob) ke stálému komplikování účetních postupů, ale bez praktických př́nosů. Mnoho předchozích modifikací účetního systému přinášelo více možností pro uplatnění metod řízení než dnešní postupy. Chybou bylo, že nebyly využívány tak, jak měly (neustálé úpravy plánu jakožto řídící veličiny). Pravdou je, že byly více direktivní, ale současné rozvolnění účetních předpisů bez možnosti přechodu na variabilní náklady není žádným přínosem.

\subsection{Harmonizace}

Velmi často se také hovoři o harmonizaci účetních soustav jakožto postupném cíli prací na naší soustavě účetnictví. Mezinárodní harmonizací účetnictví a jejím vývojem se podrobně zabývá Nobes (2004). Jak uvádí Barteczková (2003), harmonizace účetnictví v praxi znamená přibližování se, sjednocování poprrípadě tolerování metod, postupů a struktur použivaných v účetnictví jednotlivých zemí. Jde o to, aby účetní výkaznictví bylo vzájemně srovnatelné s ostatními zeměmi, které jsou pod vlivem IAS.

Výsledek patnácti let harmonizace je však takový, že jsou celé oblasti, kde naše výkazy se zahraničními srovnatelné nejsou, a musí se provádět poměrně složité převody. Nejvýraznějším prŕíkladem je naše specifická podoba leasingu, která je v přímém rozporu s tím, co ř́ká obecná ekonomie: aktivum je to, co nám přináší ekonomický prospěch. Leasovaný majetek nám sice prospěch prrináší, ale $\mathrm{v}$ aktivech se neúčtuje. U některých podniků může jít o významný rozdíl ve výši vykazovaného majetku. O dalších oblastech, jako je např. navýšení hodnoty majetku, se raději ani nehovoří. $\mathrm{O}$ harmonizaci se tedy více mluví, než dělá.

Rozdíly ve vykázaných účetních hodnotách mezi naším a zahraničním účetnictvím mají další důsledky. Jedním z nich je i použitelnost výsledků finanční analýzy. Jestliže je u nás počítána z jiných hodnot vstupních údajů, není zde srovnatelnost se zahraničními výsledky. Nejvíce se to projevuje u agregovaných ukazatelů, jako je např. Altmanův index a další. Chybí tedy srovnatelnost prostorová. Protože svého času bylo zanedbáno statistické výkaznictví, chybí i srovnatelnost časová. O dopadech na rentabilitu a další ukazatele finanční analýzy bylo hovořeno již v první části textu.

Blíže harmonizaci jsou ve Slovenské republice, kde např. stavební smlouvy se již účtují podle národních standardů vycházejících z mezinárodních předpisů. Podobně je tomu i v dalších oblastech. Ale je nutno poznamenat, že činnost nadnárodních struktur působících $\mathrm{v}$ této oblasti je podrobována tvrdé kritice.

\section{Legislativní nedostatky}

\subsection{Zásoby a česká účetní legislativa}

Stav českého účetnictví se za posledních 20 let změnil. Většinou k lepšímu, ale také v něm tvrdošíjně přetrvávají odkazy minulosti a zdá se, že není dostatečná vůle $\mathrm{k}$ jejich nápravě. Především jde o to, že v teorii se rozsáhle vyučuje o fixních a variabilních nákladech. Ale 
legislativa tyto pojmy nezná. Projdeme-li všechny př́islušné předpisy, tato slova tam nenajdeme. Dá se říci, že česká účetní legislativa je $\mathrm{v}$ podstatě proti řídící, proticontrollingová. Protože souhrnná kritika by byla př́liš rozsáhlá, dokumentování tohoto stavu je možno provést na oblastech, která se bezprostředně týká nákladového controllingu.

Na příkladu účtování zásob si ukážeme, kde jsou základní i méně důležité nedostatky. Během svého nedávného vývoje se účtování zásob stalo z poměrně jednoduché věci velmi komplikovanou záležitostí. Když si vezmeme jenom vývoj v posledních dvou desetiletích, pak zjišt’ujeme, že došlo ke změnám, které charakterizuje následující text.

Do účtování zásob zasáhlo i zavedení DPH. Vrácené zásoby se z tohoto hlediska stávají velmi komplikovanou záležitostí. I když se mluví o úplném oddělení účetnictví od daní, a myslí se tím zejména daň z př́ijmu, pak jiná daň - DPH je s účtováním zásob svázána velice pevně.

\section{Náklady spojené s pořízením zásob}

Účtování nákladů spojených s pořízením zásob (např. dopravné) bylo dříve nákladem období, nyní se o ně zvyšuje cena zásob. Racionální účtování této a podobných položek předpokládá vznik plánované ceny a její rozpouštění do ceny zásob. Účtování podle skutečných nákladů u větších podniků není reálné.

S dodávkou zásob, zejména zboží, souvisí rovněž celá velká oblast účtování obalů. Ta $\mathrm{z}$ legislativy o účtování zásob vypadla. Přestože je $\mathrm{z}$ hlediska svého objemu stále významnější, je nyní ponecháno na účetních jednotkách, at' se s ní vypořádají samy, jak umí. Ve spojitosti se změnami DPH (dřive plnění osvobozené, poté podléhající dani a nyní opět osvobozené) se jedná o oblast, které se raději vyhnou i odborné časopisy.

\section{Skutečná versus plánovaná cena}

Plánovaná cena implikuje vznik středisek, konkrétně střediska autodopravy a zajištění celého rozpočtového a kalkulačního procesu. V legislativě se předpokládá, že existují střediska, ale v žádném legislativním textu to otevřeně řečeno není. Střediskové hospodaření je zamlčeno, přitom účty a postupy vycházejí z této myšlenky. Např. u zásob je postup účtování 112/622 v tomto př́padě je 622 vnitropodnikovým výnosem střediska dopravy a je eliminací nákladů vzniklých při provozování autodopravy. Externí výnos při provozu vlastních vozidel nevzniká. Celá řada dalších účtů má podobný charakter. Pokud by zákon o účetnictví měl vyjadřovat tyto skutečnosti, pak by v základním textu mělo být např́klad toto: Účetní systém je v zásadě založen na principu vyprodukovaného hospodářského výsledku. Základní postupy účtování vychází z odpovědnostně vedeného účetnictví. Zároveň se připouští i jiné postupy, které jsou upraveny legislativou nižší právní síly“.

\section{Náklady skladování zásob}

Přitom existuje další rozhodující položka spojená s účtováním zásob, a to jsou náklady spojené se skladováním zásob. U některých položek zásob, např. u velkých náhradních dílů, může být tato položka velmi významná, někdy větší než dopravné. Přitom je $\mathrm{v}$ předpisech zcela zanedbána a nepřičítá se (mimochodem podle mezinárodního účetního standardu IAS 2 tyto velké náhradní díly do zásob vůbec nepatří). Reálné zobrazení ceny zásob, ke kterému zřejmě směřovala úprava $\mathrm{z}$ ceny pořízení na cenu pořizovací, tak zůstává na poloviční cestě. Je otázkou, proč už při složitějším účtování zásob nejsme zcela důslední a nepočítáme i s ostatními položkami, jako je tomu např. v některých sousedních zemích (napřr. Německo). V souladu s IAS 2, který nehovoří přímo o skladovacích nákladech, lze jistě najít metody, jak tyto položky zjišt'ovat. 


\section{Kalkulační účty}

Zařazení kalkulačních účtů 111 a 131 do aktiv je systémovou chybou. Tyto účty byly historicky vždy zařazeny do pasiv. Pokud tomu tak je, pak nemusí docházet k účtování na konci a na začátku roku, kdy se zůstatky těchto účtů přeúčtovávají na pasiva (kam správně patří) a pak zase zpět. Kromě toho se chybně vyjadřuje i sama podstata věci: jestliže převezmu zásoby na sklad, pak samožrejmě dlužím dodavateli. Pokud by byla dodávka $\mathrm{z}$ formálního nebo věcného hlediska nesprávná, pak by na sklad vůbec neměla být přijata (neměl by být vystaven doklad - př́ijemka) a měla by být vrácena dodavateli. Současný stav navozuje situaci, kdy zásoby jsou odběratelem převzaty, a přesto nevzniká žádný dluh a ani se mi nezvýšil majetek. Pak je toto účtování jen jakýmsi převzetím do úschovy.

\section{Odchylky jako nástroj řízení}

Ještě v nedávné době naše předpisy uváděly účtování v průměrné ceně (metoda váženého aritmetického průměru) nebo metodou FIFO (first in - first out). Metoda pevné ceny s odchylkou výslovně zmíněna nebyla a považovala se za odnož průměrné ceny. Proto většina software preferuje průměrnou cenu. Přitom mezinárodní účetní standard hovoří o metodě standardních nákladů jako jedné $\mathrm{z}$ metod použivaných $\mathrm{v}$ manažerském účetnictví (Lazar, 2012). Standardní náklady jsou předem stanovené náklady, které se používají zejména ve výrobních podnicích z důvodů plánování a kontroly. Metoda spočívá v tom, že podnik nejprve stanoví standardní náklady, které následně porovná se skutečností a zjistí odchylky. Následuje rozbor odchylek (zejména $z$ hlediska příčin a odpovědnosti) a učinění př́islušných opatření. Ř́zení zásob v pevné ceně pomocí vyhodnocování odchylek kvantitativních a kvalitativních, ačkoliv je teoreticky poměrně dobře rozvinuto Schrollem, Báčou a Janoutem (1960), není př́mým způsobem použitelné.

\section{Oceňování výrobků}

Jedním z nejhrubších pochybení je to, že výrobky nelze oceňovat ve variabilních nákladech. Je zde hluboký rozpor mezi ekonomickou teorií, která běžně prohlašuje toto členění nákladů za základ řídících procesů, a legislativou, která kapacitní členění nákladů nezná. Pokud se pokusíme vyhledat v legislativě slovo „variabilní“, tak se tam skutečně nevyskytuje. Nelze účtovat výrobky ve variabilních nákladech - samotná legislativa je tak proti metodám řízení, proti dnes tak často skloňovaném controllingu, jehož základem je právě toto kapacitní členění nákladů (Lazar a Matušková, 2012). Pak musíme pro rozhodovací procesy konstruovat další členění nákladů nesystémově, tedy mimo systém účetnictví. Co ale brání spojit racionálně oba systémy dohromady? Naprosto zkostnatělá legislativa, konkrétně český účetní standard č. 15 - Zásoby, který používá staré kalkulační názvosloví z kalkulace úplných nákladů. Přitom již Jiroušek (1912, s. 48) píše: „Úǔty režijních výdajů se rozlišují na režie výrobní a režie všeobecné... " a jsou v podstatě charakterizovány jako variabilní a fixní náklady. Takové členění není obsaženo ani v dnešní legislativě. V podstatě jde o krok o 100 a více let zpět.

\subsection{Zásoby a mezinárodní standardy}

IAS (International accounting standards) na tom jsou poněkud lépe, ale ne zase o mnoho. Zásoby vlastní výroby (hotové výrobky, nedokončená výroba a polotovary vlastní výroby) se podle standardu IAS 2 - Zásoby oceňují v nákladech, které se přímo vztahují k jednotkám produkce. Tyto náklady zahrnují přímé náklady a systematicky alokovanou fixní a variabilní režii. Fixní režie zahrnuje např. odpisy nebo údržbu budov a zařízení, náklady na vedení společnosti a administrativu. Variabilní režijní náklady zahrnují např. nepř́mý materiál nebo nepř́mé mzdy. 
Standard dále polemizuje o rozvržení fixní režie na jednotky výroby, avšak nepředepisuje žádné konkrétní vzorce. Metoda alokace fixní režie do ocenění zásob, kterou používá IAS 2, se nazývá metoda plných nákladů (Full costing). Ve společnostech se však často (z důvodů manažerského rozhodování) používá alternativní metoda - metoda přímých nákladů (Direct costing). Tato metoda zahrnuje do ocenění zásob pouze př́mý materiál, přímé mzdy a variabilní režijní náklady, které se vztahují k výrobě. Všechny fixní náklady jsou účtovány jako náklady období. Tato metoda však není v souladu s požadavky IAS 2 - Zásoby, a proto pokud společnost $\mathrm{v}$ rámci manažerského účetnictví používá metodu prŕmých nákladů, je nutno výsledky pro potřeby finančního účetnictví upravit.

Z dikce standardu dále vyplývá, že pro ocenění zásob vlastní výroby jsou preferovány skutečné náklady. V odstavcích 21 a 22 revidovaného IAS 2 je však uvedeno, že pro „pohodlí“ lze použít i tzv. metody standardních nákladů nebo metody maloobchodního prodeje, pokud se jejich výsledky přibližují ke skutečným nákladům.

Praktické použití IAS 2 - Zásoby tedy přináší u nás často problémy zcela zásadní. V první řadě je vždy třeba jednoznačně určit, zda se v konkrétní situaci má vůbec tento standard použít. Důvody byly již zmíněny výše v této kapitole. Naprríklad oblast významných a dlouhodobých náhradních dílů neřeší IAS 2, ale IAS 16, problematiku rozpracovanosti a tedy nedokončené výroby u dlouhodobých zakázek včetně dlouhodobých služeb řeší IAS 11 a IAS 18, oblast biologických aktiv je řešena IAS 41, oblast finančních nástrojů je řešena IAS 32 a IAS 39. Všechny tyto standardy mají odlišné př́stupy než IAS 2 - Zásoby. I při oceňování zásob nelze tedy vycházet pouze z dikce IAS 2. Pokud chceme důsledně aplikovat tento standard, je k tomu nutná znalost všech IAS/IFRS, jejich logiky, vazeb a zdůvodnění závěrů.

\section{3 Účetní programy a zásoby}

Zbývá se zamyslet, do jaké míry k tomuto neutěšenému stavu přispívají i účetní software. Prvotní dojem všech programátorů, kteří nejsou nijak dotčeni účetnictvím, je takový, že nejjednodušší je začít u zásob, nebot' jde vlastně jenom o př́ijemky a výdejky. Navíc legislativa je napsána tak, že pro programátory z toho nejprve vyplývala metoda FIFO, postupně ale téměř všichni přešli na průměrné ceny, a nejlépe tak, že se průměrná cena přepočítává př̀i každém pohybu zásob.

Tímto zpracováním ale zcela vylučují řízení středisek - všechna střediska musejí mít cenu vstupního materiálu stejnou po celé rozpočtové období - jinak údaj o spotřebě materiálu $\mathrm{v}$ jednotlivých střediscích uvedený $\mathrm{v}$ rozborech hospodaření je prakticky bezcenný. Odchylky (jak bylo zmíněno výše) mezi pevnou cenou, za kterou je materiál vydáván střediskům, a jejich nákupní cenou je výsledkem činnosti střediska zásobování. Zde pokračuje i hodnocení činnosti tohoto stř̌ediska. Procentní přirážka k nákupní ceně materiálu, která kryje činnost zásobovacího střediska, je velmi důležitým ukazatelem jeho výkonnosti. Pohledové hodnocení pracovníků nákupu je velmi zavádějící. Musíme být schopni spočítat toto procento. U nejhorších pracovníků se pohybuje až okolo $50 \%$, u nejlepších mezi 4 až $5 \%$. U větších podniků je toto nákladové zatížení tak významné, že přímo ohrožuje jejich konkurenční schopnost.

Jestliže obrátíme svou pozornost k samotné legislativní analýze účetních programů, tak zde můžeme najít i naprosté legislativní zmetky. Nejkřiklavějším př́ikladem je zde program jisté nejmenované firmy, kde slevy při prodeji zásob jsou účtovány jako náklad. Existence celoevropského předpisu o zákazu kompenzace mezi náklady a výnosy je zde naprosto 
ignorována. Program se běžně prodává na trhu a zákazníkům ani nevadí, že zavádí novou nákladovou položku ,slevy na tržbách“.

\section{Prosté omyly}

Podobně se lze setkat $\mathrm{s}$ účtováním bonusu do nákladů (mělo jít o krácení výnosů). Je to porušení základního principu o zákazu kompenzace, který platí celoevropsky. Stává se to tím, že problém řešíme na nižší úrovni (v tomto prípadě na účtech) a „zapomeneme“ na základní účetní zásady. Platí zde pouze výjimka kompenzace (vyrovnání, započítání) u závazků a pohledávek vůči jedné fyzické či právnické osobě, které mají splatnost do jednoho roku, ale je zakázáno vzájemné vyrovnávání nákladů a výnosů nebo př́ijmů a výdajů. Takže už z principu navrhujeme, že by mělo být účtováno dle následující tabulky.

Tabulka 1: Účtování bonusu při prodeji zboží

\begin{tabular}{|c|c|c|c|}
\hline \multirow{C}{\text{C.}}{} & Účetní př́pad & MD & Dal \\
\hline \multirow{2}{*}{1.} & Vystavena faktura na prodané zboží - plná cena & 311 & 604 \\
\cline { 2 - 4 } & - bonus & $604 . \mathrm{AE}$ & 311 \\
\hline
\end{tabular}

Zdroj: vlastní zpracování

Jak je z tabulky patrné, nákladový účet by se tam neměl vůbec objevit. Je to jeden z častých omylů, kdy v zaujetí pro drobnosti dojde k porušení ustanovení i normy nejvyššího řádu. Při zkoumání po vzniku tohoto pochybení jsme došli až $\mathrm{k}$ jeho původu. $\mathrm{V}$ jednom internetovém článku je k poskytnutí bonusu uveden následující výklad (Fučíková, 2011):

Bonus může dodavatel odběrateli poskytnout za podmínky, že odběratel odebral určité množství zásob nebo překročil stanovenou hodnotu fakturace. Může dojít k těmto způsobům poskytnutí bonusu dodavatelem:

- ihned při vystavení faktury. Odběratel o tuto částku sníží cenu fakturovaných zásob.

- dodatečně po vystavení faktury. Odběratel účtuje bonus do výnosů na účet 648 , resp. na účet 668. Tento způsob neovlivňuje DPH.

- dodavatel bezúplatně dodá zásoby odběrateli, např. 10 ks zboží navíc zdarma. Tento způsob neovlivňuje DPH.

Dodavatel zaúčtuje poskytnutí bonusu do provozních nákladů na účet 548, resp. na účet 568 .

Tento výklad však nerespektuje základní účetní zásady, kdy při nákupu zásob se zvyšují aktiva výměnou za peníze (A-A), nebo přes časový posun prostřednictví závazků (A-P-A). Jde tedy o pohyb na stavových účtech (rozvaha). Při dalším pohybu majetku pak dojde $\mathrm{k}$ přechodu na tokové účty (výsledovka). Náklady představují snižování aktiv. Tyto operace jsou legislativně ošetřeny (FIFO, průměrná cena, pevná cena s odchylkou, protokol o škodách, protokol o ztrátě, loupeži, protokol o opravných položkách atp.). Naproti tomu výnosy představují zvyšování aktiv. Vztah mezi náklady a výnosy je znázorněn v následujícím schématu:

Obrázek 2: Vztah nákladů a výnosů při účtování

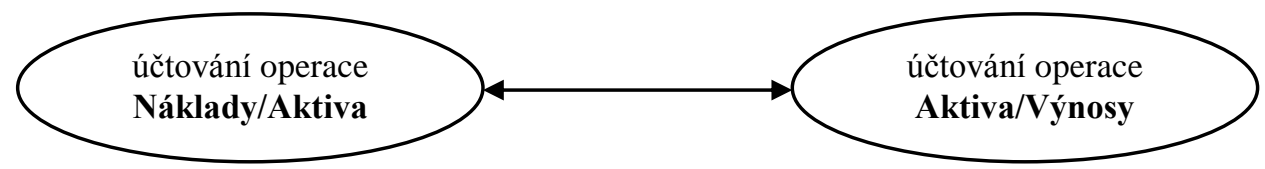

Zdroj: vlastní zpracování 
Nikdy však nelze účtovat operace Náklady/Výnosy, jak je uvedeno v internetovém př́kladu, který zobrazuje následující tabulka.

Tabulka 2: Chybné účtování bonusu u dodavatele

\begin{tabular}{|c|l|r|c|c|}
\hline \multicolumn{1}{|c|}{ Č. Účetní př́pad } & Částka & MD & Dal \\
\hline 1. & $\begin{array}{l}\text { Faktura vystavená na prodané zboží - } \\
\text { poskytnuta sleva z důvodu překročení odběru } \\
\text { určeného množství zboží }\end{array}$ & & \\
\hline a) cena bez daně & $500000 \mathrm{Kč}$ & 311 & 604 \\
\hline & b) bonus & $100000 \mathrm{Kč}$ & 548 & 311 \\
\hline & c) $21 \%$ DPH & $84000 \mathrm{Kč}$ & 311 & 343 \\
\hline
\end{tabular}

Zdroj: Fučíková (2011) + vlastní zpracování

Pro dodržení základních účetních zásad je nutno zvolit složitější postup účtování, který je zachycen v tabulce č. 3. Rovněž výsledovka by ztratila smysl.

Tabulka 3: Správné účtování bonusu u dodavatele

\begin{tabular}{|c|l|c|c|c|}
\hline \multicolumn{1}{|c|}{ Č. Účetní případ } & Částka & MD & Dal \\
\hline \multirow{1}{*}{1.} & $\begin{array}{l}\text { Faktura vystavená na prodané zboží - } \\
\text { poskytnuta sleva z důvodu překročení odběru } \\
\text { určeného množství zboží }\end{array}$ & & & \\
\cline { 2 - 5 } & a) cena bez daně & $500000 \mathrm{Kč}$ & 311 & $604 / \mathrm{AE}$ \\
\cline { 2 - 5 } & b) bonus & $100000 \mathrm{Kč}$ & $604 / \mathrm{AE}$ & 311 \\
\cline { 2 - 5 } & c) $21 \%$ DPH & $100000 \mathrm{Kčc}$ & 504 & 343 \\
\hline \multirow{2}{*}{2.} & Výdejka na vyskladněné zboží & & \\
\hline
\end{tabular}

Zdroj: vlastní zpracování

Při chybném způsobu účtování by navíc došlo k nepř́ípustnému zásahu do způsobu ocenění majetku. Tím, že je poskytnuta odběrateli sleva (bonus), nelze změnit ocenění majetku (zásob). Také údaje finanční analýzy by byly zkreslené.

\section{Závěr}

Účetnictví je v České republice stále poměrně často chápáno především jako daňové, tj. zaměřené primárně na zjištění daňového základu. $Z$ tohoto důvodu jsou pak často podceňovány, prŕípadně zcela opomíjeny operace, které nemají bezprostřední vliv na daňový základ. Podobně je tomu i u operací, jejichž cílem je zajistit časovou a věcnou srovnatelnost. V účetnictví je však zapotřebí zachycovat všechny výrobní procesy v účetní jednotce, aby byly dodrženy všeobecně uznávané účetní zásady tak, aby účetní závěrka podávala věrný a poctivý obraz předmětu účetnictví a finanční situace účetní jednotky.

V systému účetnictví se však vyskytují mnohé nedostatky, které mohou negativně ovlivnit vypovídací schopnost účetní závěrky jednotlivých podniků. Snahou př́spěvku bylo analyzovat a zhodnotit určité nedostatky ve vybraných oblastech (systémové, legislativní aj.) se zaměřením na problematiku zásob. Tyto nedostatečnosti jsou ilustrací současného neutěšeného stavu v normotvorné činnosti. Není síly ani instituce, která by daný stav změnila. Většinou jde o nezájem angažovat se $\mathrm{v}$ problémových oblastech a vystavovat se kontroverzním diskuzím. Existují sice metodická pracoviště na ministerské úrovni, ale jejich výstupy jsou tristní. Nezbývá než pokračovat v sisyfovské výkladové práci. Lze jen vyjádřit naději, že řešení problémů neustrne na mrtvém bodě a pečlivou analýzou dospěje k tomu, 
že je zapotřebí provést alespoň dílčí úpravy legislativy, zejména $\mathrm{v}$ oblasti vztahující se $\mathrm{k}$ řízení podniků.

\section{Literatura}

[1] BARTECZKOVÁ, I. 2003. Accounting and tax harmonization in the Czech Republic before entry into the European Union in the context of small and medium-sized enterprises. Acta academica karviniensia, 03(2), 5-14. ISSN 1212-415X.

[2] České účetní standardy pro účetní jednotky, které účtují podle vyhlášky č. 500/2002 Sb., ve znění pozdějších předpisů. $M F C \check{C} R$ [online]. [vid. 2. srpna 2014]. Dostupné z: http://w ww.mfcr.cz/cs/verejny-sektor/regulace/ucetnictvi/pravni-ramce

[3] CHRISTENSEN, H. B. a V. V. NIKOLAEV, 2013. Does Fair Value Accounting for Non-Financial Assets Pass the Market Test? [online]. Chicago: SSRN [vid. 10. srpna 2014]. Dostupné z: http://papers.ssrn.com/sol3/papers.cfm?abstract_id=1269515

[4] FUČÍKOVÁ, J., 2011. Účtování reklamací a slevy z ceny [online]. 1. prosinec 2011 [vid. 12. srpna 2014]. Dostupné z: http://www.uctovani.net/clanek.php?t=Uctovani-reklamacia-slevy-z-ceny\&idc $=57$

[5] JIROUŠEK, J., 1912. Účetni systém: psáno pro zkušené účetní nikoli začátečníky. Praha: Ústav ku podpoře průmyslu.

[6] KOVANDA, L., 2009. Jak zničit kapitalismus? Účetně. Týden [online]. 13. březen 2009 [vid. 10. srpna 2014]. Dostupné z: http://kovanda.blog.tyden.cz/clanky/2817/jak-znicitkapitalismus-ucetne.html

[7] LAZAR, J. a S. MATUŠKOVÁ, 2012. Variabilní a fixní náklady z pohledu ekonomické teorie a podnikového ekonomického řízení. Politická ekonomie, 12(2), 245-264. ISSN 0032-3233.

[8] LAZAR, J., 2012. Manažerské účetnictví a controlling. Praha: GRADA Publishing. ISBN 978-80-247-4133-8.

[9] Mezinárodní účetní standardy IAS/IFRS [online]. [vid. 2. srpna 2014]. Dostupné z: http:// www.iasplus.com/en/standards

[10] NOBES, C. W., 2004. Developments in the International Harmonization of Accounting. Cheltenham: Edward Elgar Publishing. ISBN 1843760975.

[11] SCHROLL, R., J. BÁČA a J. JANOUT, 1960. Evidence nákladů na výrobu a kalkulace vlastnich nákladů v průmyslu. Praha: Orbis.

[12] SHORTRIDGE, R. T., A. SCHROEDER a E. WAGONER, 2006. Fair-Value Accounting (Analyzing the Changing Environment). CPA Journal [online]. duben 2006 [vid. 10. srpna 2014]. Dostupné z: http://www.nysscpa.org/cpajournal/2006/406/essential s/p37.htm

[13] Směrnice Evropského parlamentu a Rady 2013/34/EU, o ročních účetních závěrkách, konsolidovaných účetních závěrkách a souvisejících zprávách některých forem podniků, o změně směrnice Evropského parlamentu a Rady 2006/43/ES a o zrušení směrnic Rady 78/660/EHS a 83/349/EHS. KAČR [online]. [vid. 2. srpna 2014]. Dostupné z:http://www. kacr.cz/smernice--eu

[14] Vyhláška č. 500/2002 Sb., kterou se provádějí některá ustanovení zákona č. 563/1991 Sb., o účetnictví, ve znění pozdějších předpisů, pro účetní jednotky, které jsou podnikateli účtujícími v soustavě podvojného účetnictví, ve znění pozdějších předpisů. 
Portál veřejné správy [online]. [vid. 2. srpna 2014]. Dostupné z: http://portal.gov.cz/app/ zakony/zakonPar.jsp?idBiblio=54043\&fulltext=vyhl C3 A1 C5 A1ka 20500 2F2002 $\& n r=\& p a r t=\& n a m e=\& r p p=15 \#$ local-content

[15] Zákon č. 561/1991 Sb., o účetnictví, ve znění pozdějších předpisů. Portál veřejné správy [online]. [vid. 2. srpna 2014]. Dostupné z: http://portal.gov.cz/app/zakony/zakonPar.jsp?i dBiblio=39611\&fulltext=z C3 A1kon 20o 20 C3 BA C 4 8Detnictv $\sim$ C3 AD\&nr $\&$ part $=\&$ name $=\& \mathrm{rpp}=15 \#$ local - content 